\title{
Article
}

\section{Does Cryptocurrency Hurt African Firms?}

\author{
Mina Sami ${ }^{1, *(\mathbb{D})}$ and Wael Abdallah ${ }^{2}$ \\ 1 Department of Economics, American University in Cairo, New Cairo 11835, Egypt \\ 2 Department of Management, American University in Cairo, New Cairo 11835, Egypt; \\ wael.mostafa@aucegypt.edu \\ * Correspondence: mina_sami@aucegypt.edu
}

\begin{abstract}
This paper aimed to assess the effect of the cryptocurrency market on firms' market value, especially on the sectoral level, in Africa. To reach the study's main goal, the authors adopted the Panel-Corrected Standard Errors (PCSEs) and Panel Double-Clustered Standard Errors (PDCSEs). Using firm-level data, the results of this study can be summarized as follows: (a) The cryptocurrency market hurts the firm market value in Africa. (b) The firms operating across different sectors respond disproportionally to the cryptocurrency market. For instance, the sectors that offer low returns in Africa (industrial, energy, financial) negatively respond to the cryptocurrency market, while the sectors that offer high returns (real estate and information technology) are not significantly affected. (c) The cryptocurrency market has a perverse effect on less experienced and highly indebted firms.

(d) The consistent policies of governments to ban cryptocurrency do not work efficiently.
\end{abstract}

Keywords: cryptocurrency; sector; Africa; market cap

JEL Classification: B26; G11; G32

check for

updates

Citation: Sami, Mina, and Wael Abdallah. 2022. Does Cryptocurrency Hurt African Firms? Risks 10: 53. https://doi.org/10.3390/ risks10030053

Academic Editor: Dimitrios Koutmos

Received: 20 January 2022

Accepted: 18 February 2022

Published: 1 March 2022

Publisher's Note: MDPI stays neutral with regard to jurisdictional claims in published maps and institutional affiliations.

Copyright: (c) 2022 by the authors. Licensee MDPI, Basel, Switzerland. This article is an open access article distributed under the terms and conditions of the Creative Commons Attribution (CC BY) license (https:// creativecommons.org/licenses/by/ $4.0 /)$.

\section{Introduction}

Over the last decade, cryptocurrency transactions in Africa have considerably increased. By December 2021, the cryptocurrency users in this region reached 32 million, representing 2.6\% of the continent's population (TripleA 2021). Given that Africa accounts for $60 \%$ of worldwide mobile money transactions, future cryptocurrency transactions in Africa are expected to increase (Masie 2021).

Previous studies suggested the prominence of a significant relationship between the cryptocurrency market and many macroeconomic and financial indices (Dyhrberg 2016; Kostika and Laopodis 2019; Trabelsi 2018; Sami and Abdallah 2020a, 2020b). Relative to these studies, this paper examines four main questions. (1) Does the cryptocurrency market effect overpass the macroeconomic frontiers to affect the microeconomic entities (i.e., firms) in Africa? (2) If so, how are African firms affected? (3) Do all firms operating across different sectors respond similarly to cryptocurrency market movements? (4) How do the firm characteristics (e.g., experience) and internal policies (e.g., debt policy) shape this effect?

Several reasons made Africa an interesting region to be covered in this study. First, African countries have struggled with infrastructure issues for a long period. This vital challenge has consistently affected the investors' returns (Möykkynen and Pantelias 2021). Conspicuously, the continent remains challenged in securing a suitable level of financial services. By 2021, we note that $57 \%$ of the continent's citizens were still unbanked. Currently, cryptocurrency networks have become more user-friendly than traditional banking and money-transfer systems. Second, Africa has the world's largest share of retail-sized transfers in the cryptocurrency market, accounting for almost $30 \%$ of all transactions. (ChainAnalsysis 2020), compared with other worldwide regions, whose retail-sized transfers are below $20 \%$. Third, many African countries have the most significant share of cryptocurrency users 
globally. For example, cryptocurrency users account for $8.5 \%, 7.1 \%$, and $6.3 \%$ of the population in Kenya, South Africa, and Nigeria, respectively. (TripleA 2021).

The authors exported African firm data from Datastream. They compiled them with cryptocurrency data from CoinDesk over the period 2013-2021 monthly. The methodology was based on the Panel-Corrected Standard Errors (PCSEs) and the Panel Double-Clustered Standard Errors (PDCSEs) to overcome serial autocorrelation, cross-sectional dependence, and heteroskedasticity problems.

The results of this study can be summarized as follows: First, the cryptocurrency market has adverse effects on African firms. African investors are drawn to the cryptocurrency market for its attractive returns. The behavior of those investors is likely to affect the African firms' market value. Second, the firms operating across different sectors do not respond similarly to the cryptocurrency market. For instance, the sectors that faced low returns over the last decade in Africa (e.g., energy, financial, industrial) are the top sectors struggling with the perverse effects of the cryptocurrency market. On the other hand, the competitive sectors that realized high returns (e.g., real estate and information technology) are not significantly affected ${ }^{1}$.The experienced firms in the market and those with modest debt levels are noticeably less affected than the less experienced and heavily indebted firms. Finally, government regulations limiting cryptocurrency transactions are ineffective.

The remainder of the paper is organized as follows. A review of the chosen literature is presented in Section 2. The methodology and data are described in Section 3. The empirical findings are presented in Section 4. Robustness checks are presented in Section 5. Section 6 provides the conclusions.

\section{Literature Review}

A strand of research has focused on studying the cryptocurrency market's interaction with other financial and macroeconomic assets. Bouri et al. (2018) studied the return and volatility spillover between cryptocurrency and four traditional financial assets (stocks, commodities, currencies, and bonds). Their findings proved that the cryptocurrency market is not isolated and connected to other assets, in particular commodities. In terms of coskewness and the linkage of market returns to the cryptocurrency market, Matkovskyy and Jalan (2019) discovered significant contagion impacts from five equity indices. They concluded that risk-averse investors drop risky cryptocurrency markets from their portfolios and invest in safe financial market assets during a crisis. Using the quantile cross-spectral approach, Baumöhl (2019) examined the connectedness between forex and cryptocurrencies. This analysis revealed a negative relationship between these two assets. Thus, investors can benefit from diversification by investing in both assets simultaneously. More recently, Yang (2020) confirmed a significant nonlinear relationship between cryptocurrency and Taiwan's stock market.

Jareño et al. (2020) analyzed the sensitivity between the return of cryptocurrencies and traditional financial assets. They found that the returns of the U.S. stock market and gold were strongly correlated with the returns of cryptocurrencies. On the contrary, cryptocurrencies' returns were negatively correlated with the nominal interest rates and oil returns in high and low quantiles, respectively. Thus, cryptocurrency can act as a safehaven asset during financial distress. Using a DCC GARCH model analysis, Rudolf et al. (2021) examined the feasibility of cryptocurrencies as an alternative hedging investment to gold and major stock indices. They showed that cryptocurrencies compete with gold and can be considered virtual gold. More recently, Doumenis et al. (2021) showed that cryptocurrencies' returns had a relatively high level of volatility compared to other financial assets (S\& P 500, gold, and treasury bonds). They also found a positive correlation between the volatility of cryptocurrencies' prices and the three financial assets before and during the COVID-19 pandemic. The authors highlighted that cryptocurrencies are often identified as a new digital gold (speculative investment asset) and do not appear to function as a currency. As a global picture, these studies concluded that the volatility of cryptocurrency market capitalization impacts various financial assets, and thus, firms might be affected. 
On the other hand, Trabelsi (2018) examined the connectedness between cryptocurrency markets and conventional assets (traditional currencies, stock market indices, and commodities). The author provided evidence of no significant spillover between cryptocurrencies and other financial asset markets. Kostika and Laopodis (2019) did not find significant short or long stochastic trends between cryptocurrencies and traditional financial assets (stock returns and exchange rates). Zeng et al. (2020) obtained similar findings that cryptocurrencies have a weak correlation with conventional financial assets (stocks, oil, and gold). Gil-Alana et al. (2020) also investigated the bilateral linkages between six cryptocurrencies and six stock market indexes. They found no co-integration between cryptocurrencies and the stock market indices.

Investors' choice to maintain an efficient portfolio will remain a key channel through which the cryptocurrency market affects macroeconomic and financial indicators, as well as the micro-entities such as firms. The ultimate goal of any investor is to construct a portfolio that combines assets that maximize portfolio returns with an acceptable level of risk. During the 2000s, Cryptocurrencies' inclusion in traditional portfolios containing stocks and bonds received substantial attention from investors, policy-makers, and researchers (Sami and Abdallah 2020a). The investment pattern of the individuals can explain this attention. Conspicuously, investment decisions are a function of observable market characteristics, such as prices, volumes, and market capitalizations, rather than fundamental values such as accounting or economic data. Despite prominent volatility, their high average returns and low correlations have established cryptocurrencies as alternative investment assets for portfolio and risk management (Petukhina et al. 2021). Corbet et al. (2018) concluded that investors seeking to benefit from short-term diversification should consider the cryptocurrencies' risk and return behavior with other financial assets. In line with this, Corbet et al. (2020) confirmed the benefit of short-term diversification when examining the relationships between Kodak, cryptocurrency, and stock market index returns. They asserted a significant increase in Kodak's stock price and volatility following the Kodakcoin announcement. Corbet et al. (2021) showed that cryptocurrency market liquidity increased significantly during the pandemic. They suggested that cryptocurrencies act as safe-haven investments during substantial financial market stress periods. Culjak et al. (2022) confirmed that investors should consider the selected asset's income ratio dynamics in portfolio construction to identify and quantify the investment risk. Investors' appetite for achieving the highest possible return in the short term will push them to invest in cryptocurrencies and drop other traditional financial assets, i.e., stocks. Consequently, firms' stock prices might drop and adversely affect firms. Although many recent studies focused on some countries in the African continent to measure financial, macroeconomic, and social indicators (Said et al. 2019), few studies are focusing on cryptocurrencies and their potential effects. The existent ones predict an important expansion in the cryptocurrency market. For instance, Mazambani and Mutambara (2020) predicted that South African investors have a high probability of adopting and expanding their investments in cryptocurrency, while Agbo and Nwadialor (2020) suggested significant impacts of the cryptocurrency market in the African economies, implying a decline in the effectiveness of the major government policies such as the monetary policy. To the authors' knowledge, no studies have been devoted to assessing cryptocurrencies' effect on firms, in particular in Africa.

\section{Methodology and Data}

\subsection{Methodology}

As the authors dealt with a panel dataset, they started by applying panel regression techniques, mainly fixed and random effects models. To select the most appropriate model, they implemented the Hausman test.

The preceding models have an important limitation: they assume no cross-section and time correlation in the standard errors. To overcome these limitations, Beck and Katz (1995) proposed estimating the error covariance across clustered time periods. This technique efficiently reduces the biasness in the standard errors and is known as Panel-Corrected Stan- 
dard Errors (PCSEs). Previous studies adopted this methodology by clustering either across time to control serial autocorrelation or firms for cross-sectional dependence. Cameron et al. (2011) and Thompson (2011) introduced the Double Panel-Corrected Standard Errors (DPCSEs) to correct for the two dimensions at the same time.

The purpose of the empirical methodology is to estimate the following model:

$$
Y=Z \gamma+\epsilon
$$

where $Y$ is a vector $(n \times 1)$ reflecting the dependent variable, Stock Market Cap (Stock $\mathrm{MC})$, in this case. $Z$ is a matrix $(k \times n)$ including the independent variables that are firmspecific and country-specific and the cryptocurrency variable. This matrix also includes the individual and time-specific effects. Finally, $\epsilon$ is a vector $(n \times 1)$ representing the error terms assumed to be independent and identically distributed.

White (1980) defined $V(\hat{\gamma})$ as the matrix of the covariance matrix of size $(k \times k)$. The specification of this matrix can be written as follows:

$$
V(\hat{\gamma})=\left(Z^{T} Z\right)^{-1}\left(Z^{T}\left[\sigma^{2} \Omega\right] Z\right)\left(Z^{T} Z\right)^{-1}
$$

This matrix is also known as the sandwich matrix, where $\Omega$ is a positive definite matrix. The covariance matrix of errors is written in the form $\sigma^{2} \Omega$.

According to Beck and Katz (1995),

$$
\Omega=\sum_{N} \otimes I_{T}
$$

$I_{T}$ is an identity matrix, and $\mathrm{T}$ is the time, where $t=1, \ldots, T$, while $\hat{\Sigma}_{N}$ can be estimated as follows,

$$
\hat{\sum}_{N}=\frac{\sum_{i=1}^{N} \hat{\epsilon}_{t} \hat{\epsilon}_{t}^{T}}{N}
$$

$\hat{\epsilon}_{t}$ is the vector representing the estimated residual, and $\mathrm{N}$ is the number of firms in the data $n=1, \ldots, N$.

The Double Panel-Corrected Standard Errors (DPCSEs) were introduced by Thompson (2011) and Cameron et al. (2011), who defined $V(\hat{\gamma})_{c x T}$ as the covariance matrix including firm and time clustering.

$$
V(\hat{\gamma})_{c x T}=V(\hat{\gamma})_{c x}+V(\hat{\gamma})_{c T, l}-V(\hat{\gamma})_{W H}
$$

where $V(\hat{\gamma})_{c x}$ is the firm clustering covariance and is calculated as follows:

$$
V(\hat{\gamma})_{c x}=\sum_{n=1}^{N} Z_{n}^{T} \epsilon_{n} \epsilon_{n}^{T} Z_{n}
$$

$V(\hat{\gamma})_{c T, l}$ is the time-clustered covariance and is estimated by adding to the sum of covariances one more lag at different points in time. This addition should be related to the covariances between the observations per firm. The study assumed $L$ as the maximum lag where $l=1, \ldots, L$ (Thompson 2011):

$$
V(\hat{\gamma})_{c T, l}=\sum_{t=1}^{T} Z_{t}^{T} \epsilon_{t} \epsilon_{t-l}^{T} Z_{t-l}
$$

$V(\hat{\gamma})_{W H}$ is the White estimator calculated as follows:

$$
V(\hat{\gamma})_{W H}=\sum_{t=1}^{T} \sum_{n=1}^{N}\left(Z_{n t} \epsilon_{n t} \epsilon_{n, t-l}^{T} Z_{n, t-l}^{T}\right)
$$


Finally, based on Equations (6)-(8), $V(\hat{\gamma})_{c x T}$ in Equation (5) can be rewritten as follows:

$$
V(\hat{\gamma})_{c x T}=\sum_{n=1}^{N} Z_{n}^{T} \epsilon_{n} \epsilon_{n}^{T} Z_{n}+\sum_{t=1}^{T} Z_{t}^{T} \epsilon_{t} \epsilon_{t-l}^{T} Z_{t-l}-\sum_{t=1}^{T} \sum_{n=1}^{N}\left(Z_{n t} \epsilon_{n t} \epsilon_{n, t-l}^{T} Z_{n, t-l}^{T}\right)
$$

The empirical results will provide the results of the following equation using the methodologies of Beck and Katz (1995) and Thompson (2011) to correct for the standard errors:

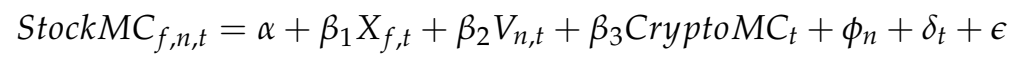

where Stock $M C_{f, n, t}$ is the stock market cap of firm $f$ originating from country $n$ at time $t$. $X_{f, t}$ is the matrix of covariates changing with firms over time (assets, debts, profits), and $V_{n, t}$ is the matrix of covariates changing with countries over time (exchange rate, money growth, trade). Crypto $M C_{t}$ is a vector changing over time including the cryptocurrency market cap over time. $\phi_{n}$ and $\delta_{t}$ are country and time-fixed effects. $\epsilon$ is the error term. Finally, $\alpha, \beta_{1}, \beta_{2}$, and $\beta_{3}$ are the parameters to be estimated.

\subsection{Data}

The authors compiled data exported from Datastream and cryptocurrency data exported from CoinDesk. The data obtained from Datastream were on the firm-level, focusing mainly on African countries with vital stock market indices, operating across many sectors and actively listed firms. Besides, the data cover all the geographical parts of the African continent. In particular, Egypt, Morocco, and Tunisia represent North Africa. Botswana, South Africa, and Zimbabwe represent the southern region. Uganda and Kenya represent Eastern Africa. Ghana and Nigeria represent Western Africa. Those countries cover almost $86 \%$ of the listed firms in the regions and include almost all top-250 firms in the region (Global-Economy 2020). The previously compiled data were merged with macro datasets exported from the Federal Reserve Economic Data and Penn World Tables on the country level. Finally, the authors were confronted with monthly panel data at the firm level from 2013 to 2021. The following table summarizes the variables included in the study, their definitions, and their sources. The detailed descriptive statistics of these quantitative variables are presented in Tables A1 and A2 in Appendix A.

\section{Empirical Results}

Tables 1-6 give the regression results for the effect of lagged cryptocurrency market cap on the stock market value. They also provide the estimated coefficients for the following firm variables: total assets, debt-to-asset ratio, and profitability, as well as the following country-level variables: money growth, exchange rate, and trade.

The test results provided at the end of Table 2 guided the authors toward the robust estimation method. We began with the Hausman test, which supported applying the fixed effects. The Pesaran CD, Wooldridge, and Breusch Pagan tests showed that the data had cross-sectional dependence, serial autocorrelation, and heteroskedasticity. These latter findings suggested a correction for the standard errors using the PCSE and DPCSE methods. It is noticeable that the standard errors between brackets changed from the PCSE to DPCSE models.

Taken as a whole, the tables paint a consistent picture that a larger market cap of cryptocurrency is associated with a lower stock market cap.

Columns (5) and (6) in Table 2 show that each 10\% increase in the cryptocurrency market cap in the previous period was associated with a decrease in the stock market value by $0.76 \%$ in the following period.

The results using the PCSE and DPCSE showed that total assets and profitability played an important role in enhancing the market value of the African firms (Dang et al. 2018; Said et al. 2018; Sami and ElBedawy 2019).

Finally, the monetary and exchange rate policies had a substantial effect on the stock market value of the African firms. This has been well documented by the current literature ( Bermudez Delgado et al. 2018; Christiano et al. 2008; Sami et al. 2020). For instance, money 
growth and higher exchange rate variables negatively affect the market value of African firms. As per the definition of the exchange rate variable, we note that an appreciation of the national currency relative to the U.S. dollar negatively affected the stock market value. Baggs et al. (2009) showed that an appreciation of the national currency was associated with a cost advantage for foreign firms. This can have substantial adverse effects on the market value, sales, and even the survival of productive domestic firms.

Table 1. Full-sample regression results.

\begin{tabular}{|c|c|c|c|c|}
\hline & \multicolumn{2}{|c|}{ Random Effects } & \multicolumn{2}{|c|}{ Fixed Effects } \\
\hline & PCSE & DPCSE & PCSE & DPCSE \\
\hline & (2) & (3) & (5) & (6) \\
\hline L. (Crypt MC) & $\begin{array}{l}-0.078^{* * *} \\
(0.008)\end{array}$ & $\begin{array}{l}-0.078^{* * *} \\
(0.011)\end{array}$ & $\begin{array}{l}-0.076^{* * *} \\
(0.008)\end{array}$ & $\begin{array}{l}-0.076^{* * *} \\
(0.012)\end{array}$ \\
\hline Total Assets & $\begin{array}{l}0.190 * * * \\
(0.044)\end{array}$ & $\begin{array}{l}0.190^{* * *} \\
(0.064)\end{array}$ & $\begin{array}{l}0.176^{* * *} \\
(0.047)\end{array}$ & $\begin{array}{l}0.176^{*} \\
(0.071)\end{array}$ \\
\hline Debt-to-Asset & $\begin{array}{c}-0.017 \\
(0.018)\end{array}$ & $\begin{array}{l}-0.017 \\
(0.022)\end{array}$ & $\begin{array}{l}-0.017 \\
(0.018)\end{array}$ & $\begin{array}{l}-0.017 \\
(0.022)\end{array}$ \\
\hline Profitability & $\begin{array}{l}0.108^{* * *} \\
(0.016)\end{array}$ & $\begin{array}{l}0.108^{* * *} \\
(0.021)\end{array}$ & $\begin{array}{l}0.108^{* * *} \\
(0.016)\end{array}$ & $\begin{array}{l}0.108^{* * *} \\
(0.021)\end{array}$ \\
\hline Money Growth & $\begin{array}{l}-0.019 \text { *** } \\
(0.005)\end{array}$ & $\begin{array}{l}-0.019^{* * *} \\
(0.006)\end{array}$ & $\begin{array}{l}-0.019 \text { *** } \\
(0.005)\end{array}$ & $\begin{array}{l}-0.019 \text { *** } \\
(0.006)\end{array}$ \\
\hline Exchange Rate & $\begin{array}{l}-0.001 \text { *** } \\
(0.0003)\end{array}$ & $\begin{array}{l}-0.001^{* * *} \\
(0.0004)\end{array}$ & $\begin{array}{l}-0.001 \text { *** } \\
(0.0003)\end{array}$ & $\begin{array}{l}-0.001^{* * *} \\
(0.0004)\end{array}$ \\
\hline Trade & $\begin{array}{l}0.524 \\
(0.557)\end{array}$ & $\begin{array}{l}0.524 \\
(0.674)\end{array}$ & $\begin{array}{l}0.514 \\
(0.558)\end{array}$ & $\begin{array}{l}0.514 \\
(0.663)\end{array}$ \\
\hline Panel FE & YES & YES & YES & YES \\
\hline Time FE & YES & YES & YES & YES \\
\hline Observations & 42,425 & 42,425 & 42,425 & 42,425 \\
\hline $\mathrm{R}^{2}$ & 0.121 & 0.121 & 0.105 & 0.105 \\
\hline Adjusted $\mathrm{R}^{2}$ & 0.121 & 0.121 & 0.092 & 0.092 \\
\hline F Statistic & $4994^{* * *}$ & $4994^{* * *}$ & $272.197^{* * *}$ & $272.197^{* * *}$ \\
\hline $\begin{array}{l}\text { Hausman Test (FE vs. } \\
\text { RE) }\end{array}$ & $45.11^{* * *}$ & & & \\
\hline $\begin{array}{l}\text { F Test for Individual } \\
\text { Effects }\end{array}$ & $1.70 * *$ & & & \\
\hline $\begin{array}{l}\text { Lagrange Multiplier } \\
\text { Test }\end{array}$ & $44.25^{* * *}$ & & & \\
\hline Pesaran CD & $348.5^{* * *}$ & & & \\
\hline Wooldridge Test & $3746^{* * *}$ & & & \\
\hline Breusch Pagan Test & $866.44^{* * *}$ & & & \\
\hline
\end{tabular}

Note: clustered standard errors in parentheses. ${ }^{* * *} p<0.01,{ }^{* *} p<0.05,{ }^{*} p<0.1$.

Table 2. Definition of the variables.

\begin{tabular}{llll}
\hline & Variable & Definition & Source \\
\hline & Stock MC & $\begin{array}{l}\text { Stock market cap per firm in } \\
\text { millions of USD transformed } \\
\text { into the logarithm form. }\end{array}$ & Datastream \\
\cline { 2 - 4 } Firm-Level Variables & Debt-to-Asset & Debt-to-asset ratio per firm. & Datastream \\
\cline { 2 - 4 } & Total Assets & $\begin{array}{l}\text { Total assets per firm } \\
\text { transformed into the } \\
\text { logarithm form. }\end{array}$ & Datastream \\
\cline { 2 - 5 } & Profitability & $\begin{array}{l}\text { Operating profit per firm in } \\
\text { millions of USD transformed } \\
\text { into the logarithm form. }\end{array}$ & Datastream \\
\hline
\end{tabular}


Table 2. Cont.

\begin{tabular}{|c|c|c|c|}
\hline & Variable & Definition & Source \\
\hline \multirow{3}{*}{ Country-Level Variables } & Money growth & $\begin{array}{l}\text { M1 money supply per region } \\
\text { is used to measure the growth } \\
\text { rate of the money supply } \\
\text { relative to the output growth. } \\
\text { The variable is expressed as } \\
\text { an index per country. }\end{array}$ & Fraser Institute \\
\hline & Exchange Rate & $\begin{array}{l}\text { Exchange rate of national } \\
\text { currency relative to the U.S. } \\
\text { currency. }\end{array}$ & Penn World Tables \\
\hline & Trade & $\begin{array}{l}\text { Income coming from trade } \\
\text { relative to GDP at purchasing } \\
\text { power parities per country. }\end{array}$ & Penn World Tables \\
\hline $\begin{array}{l}\text { Cryptocurrency-Level } \\
\text { Variable }\end{array}$ & Crypto MC & $\begin{array}{l}\text { Market cap of cryptocurrency } \\
\text { index in millions of USD } \\
\text { transformed into logarithm form. }\end{array}$ & CoinDesk \\
\hline
\end{tabular}

\subsection{Results by Firm Sector}

Table 3 dissects the results of the previous regressions by sector. The database distinguishes six main sectors: energy, financial, industrial, consumer services, Information Technology (IT), and real estate.

As a global picture, the effect of cryptocurrency had the highest perverse effect on the energy sector, followed by the industrial, consumer services, and financial sectors. We note that IT and real estate were not significantly affected by the cryptocurrency stock market. Those results go in line with the African stock market sectoral achievements over the last decade. In particular, real estate and IT realized the highest competitive returns in the regions over the last decade, while on average, the energy, financial, industrial, and consumer services sectors had relatively low and negative returns ${ }^{2}$. Conspicuously, the sectors that operated poorly lost their investors in favor of other alternative cryptocurrency markets. In contrast, the highly competitive sectors maintained their position.

Table 3. Regression results by sector.

\begin{tabular}{|c|c|c|c|c|c|c|}
\hline & \multicolumn{2}{|c|}{ Energy } & \multicolumn{2}{|c|}{ Financial } & \multicolumn{2}{|c|}{ Industrial } \\
\hline & $\begin{array}{r}\text { PCSE } \\
\text { (1) }\end{array}$ & $\begin{array}{c}\text { DPCSE } \\
\text { (2) }\end{array}$ & $\begin{array}{r}\text { PCSE } \\
\text { (3) }\end{array}$ & $\begin{array}{r}\text { DPCSE } \\
(4)\end{array}$ & $\begin{array}{r}\text { PCSE } \\
(5)\end{array}$ & $\begin{array}{c}\text { DPCSE } \\
(6)\end{array}$ \\
\hline L. (Crypt MC) & $\begin{array}{l}-0.164^{* * *} \\
(0.058)\end{array}$ & $\begin{array}{l}-0.164^{* * *} \\
(0.062)\end{array}$ & $\begin{array}{l}-0.064^{* * *} \\
(0.014)\end{array}$ & $\begin{array}{l}-0.064^{* * *} \\
(0.017)\end{array}$ & $\begin{array}{l}-0.108^{* * *} \\
(0.019)\end{array}$ & $\begin{array}{l}-0.108^{* * *} \\
(0.022)\end{array}$ \\
\hline Total Assets & $\begin{array}{l}0.639 * * \\
(0.310)\end{array}$ & $\begin{array}{l}0.639 * * \\
(0.253)\end{array}$ & $\begin{array}{l}0.103 \\
(0.079)\end{array}$ & $\begin{array}{l}0.103 \\
(0.101)\end{array}$ & $\begin{array}{l}0.330 * * * \\
(0.105)\end{array}$ & $\begin{array}{l}0.330 * * * \\
(0.124)\end{array}$ \\
\hline Debt-to-Asset & $\begin{array}{l}0.141 \\
(0.124)\end{array}$ & $\begin{array}{l}0.141 \\
(0.099)\end{array}$ & $\begin{array}{l}-0.003 \\
(0.027)\end{array}$ & $\begin{array}{l}-0.003 \\
(0.033)\end{array}$ & $\begin{array}{l}-0.077 \\
(0.048)\end{array}$ & $\begin{array}{l}-0.077 \\
(0.051)\end{array}$ \\
\hline Profitability & $\begin{array}{l}-0.089 \\
(0.112)\end{array}$ & $\begin{array}{l}-0.089 \\
(0.164)\end{array}$ & $\begin{array}{l}0.068^{* * *} \\
(0.023)\end{array}$ & $\begin{array}{l}0.068 * * \\
(0.031)\end{array}$ & $\begin{array}{l}0.082 * \\
(0.046)\end{array}$ & $\begin{array}{l}0.082 * \\
(0.046)\end{array}$ \\
\hline Money Growth & $\begin{array}{l}-0.008 \\
(0.032)\end{array}$ & $\begin{array}{l}-0.008 \\
(0.031)\end{array}$ & $\begin{array}{l}-0.012 \\
(0.009)\end{array}$ & $\begin{array}{l}-0.012 \\
(0.011)\end{array}$ & $\begin{array}{l}-0.032 \text { *** } \\
(0.011)\end{array}$ & $\begin{array}{l}-0.032 \text { *** } \\
(0.011)\end{array}$ \\
\hline Exchange Rate & $\begin{array}{l}-0.003 \\
(0.003)\end{array}$ & $\begin{array}{l}-0.003 \\
(0.002)\end{array}$ & $\begin{array}{l}-0.001 \text { ** } \\
(0.0004)\end{array}$ & $\begin{array}{l}-0.001^{* * *} \\
(0.0003)\end{array}$ & $\begin{array}{l}-0.003 \text { * } \\
(0.002)\end{array}$ & $\begin{array}{l}-0.003 \text { * } \\
(0.002)\end{array}$ \\
\hline Trade & $\begin{array}{l}1.115 \\
(2.440)\end{array}$ & $\begin{array}{l}1.115 \\
(3.030)\end{array}$ & $\begin{array}{l}0.940 \\
(0.835)\end{array}$ & $\begin{array}{l}0.940 \\
(0.911)\end{array}$ & $\begin{array}{l}-3.417^{* *} \\
(1.458)\end{array}$ & $\begin{array}{l}-3.417^{* *} \\
(1.476)\end{array}$ \\
\hline Panel FE & YES & YES & YES & YES & YES & YES \\
\hline Time FE & YES & YES & YES & YES & YES & YES \\
\hline Observations & 1623 & 1623 & 12,709 & 12,709 & 6474 & 6474 \\
\hline $\mathrm{R}^{2}$ & 0.258 & 0.258 & 0.100 & 0.100 & 0.195 & 0.195 \\
\hline Adjusted $\mathrm{R}^{2}$ & 0.238 & 0.238 & 0.086 & 0.086 & 0.181 & 0.181 \\
\hline F Statistic & $30.4^{* * *}$ & $30.4^{* * *}$ & $77.552 * * *$ & $77.552 * * *$ & $85.6^{* * *}$ & $85.6^{* * *}$ \\
\hline
\end{tabular}


Table 3. Cont.

\begin{tabular}{|c|c|c|c|c|c|c|}
\hline & \multicolumn{2}{|c|}{ Consumer Services } & & \multicolumn{2}{|c|}{ Real Estate } \\
\hline & $\begin{array}{r}\text { PCSE } \\
(7)\end{array}$ & $\begin{array}{c}\text { DPCSE } \\
(8)\end{array}$ & $\begin{array}{l}\text { PCSE } \\
(9)\end{array}$ & $\begin{array}{r}\text { DPCSE } \\
(10)\end{array}$ & $\begin{array}{r}\text { PCSE } \\
(11)\end{array}$ & $\begin{array}{r}\text { DPCSE } \\
(12)\end{array}$ \\
\hline L. (Crypt MC) & $\begin{array}{l}-0.0911^{* * *} \\
(0.015)\end{array}$ & $\begin{array}{l}-0.091^{* * *} \\
(0.020)\end{array}$ & $\begin{array}{l}-0.003 \\
(0.047)\end{array}$ & $\begin{array}{l}-0.003 \\
(0.054)\end{array}$ & $\begin{array}{l}-0.027 \\
(0.021)\end{array}$ & $\begin{array}{l}-0.027 \\
(0.022)\end{array}$ \\
\hline Total Assets & $\begin{array}{l}0.191 \text { ** } \\
(0.095)\end{array}$ & $\begin{array}{l}0.191 \\
(0.128)\end{array}$ & $\begin{array}{l}0.111 \\
(0.158)\end{array}$ & $\begin{array}{l}0.111 \\
(0.175)\end{array}$ & $\begin{array}{l}0.082 \\
(0.147)\end{array}$ & $\begin{array}{l}0.082 \\
(0.193)\end{array}$ \\
\hline Debt-to-Asset & $\begin{array}{l}-0.019 \\
(0.031)\end{array}$ & $\begin{array}{l}-0.019 \\
(0.040)\end{array}$ & $\begin{array}{l}0.074 \\
(0.092)\end{array}$ & $\begin{array}{l}0.074 \\
(0.109)\end{array}$ & $\begin{array}{l}-0.032 \\
(0.044)\end{array}$ & $\begin{array}{l}-0.032 \\
(0.060)\end{array}$ \\
\hline Profitability & $\begin{array}{l}0.113^{* * *} \\
(0.030)\end{array}$ & $\begin{array}{l}0.113^{* * *} \\
(0.038)\end{array}$ & $\begin{array}{l}0.126 \\
(0.098)\end{array}$ & $\begin{array}{l}0.126 \\
(0.141)\end{array}$ & $\begin{array}{l}0.222 * * * \\
(0.041)\end{array}$ & $\begin{array}{l}0.222 * * * \\
(0.051)\end{array}$ \\
\hline Money Growth & $\begin{array}{c}-0.012 \\
(0.010)\end{array}$ & $\begin{array}{l}-0.012 \\
(0.012)\end{array}$ & $\begin{array}{l}-0.049^{* * *} \\
(0.017)\end{array}$ & $\begin{array}{l}-0.049 \text { ** } \\
(0.020)\end{array}$ & $\begin{array}{l}-0.013 \\
(0.013)\end{array}$ & $\begin{array}{l}-0.013 \\
(0.013)\end{array}$ \\
\hline Exchange Rate & $\begin{array}{l}-0.001 \\
(0.001)\end{array}$ & $\begin{array}{l}-0.001 \\
(0.001)\end{array}$ & $\begin{array}{l}-0.001 \\
(0.003)\end{array}$ & $\begin{array}{l}-0.001 \\
(0.003)\end{array}$ & $\begin{array}{l}-0.002 \\
(0.001)\end{array}$ & $\begin{array}{l}-0.002 \text { * } \\
(0.001)\end{array}$ \\
\hline Trade & $\begin{array}{l}0.886 \\
(1.037)\end{array}$ & $\begin{array}{l}0.886 \\
(1.173)\end{array}$ & $\begin{array}{l}3.626 * \\
(2.185)\end{array}$ & $\begin{array}{l}3.626 * \\
(1.882)\end{array}$ & $\begin{array}{l}-1.550 \\
(1.681)\end{array}$ & $\begin{array}{l}-1.550 \\
(1.305)\end{array}$ \\
\hline Panel FE & YES & YES & YES & YES & YES & YES \\
\hline Time FE & YES & YES & YES & YES & YES & YES \\
\hline Observations & 13,253 & 13,253 & 2154 & 2154 & 6212 & 6212 \\
\hline $\mathrm{R}^{2}$ & 0.112 & 0.112 & 0.090 & 0.090 & 0.105 & 0.105 \\
\hline Adjusted $\mathrm{R}^{2}$ & 0.098 & 0.098 & 0.069 & 0.069 & 0.089 & 0.089 \\
\hline F Statistic & $91.4^{* * *}$ & $91.4^{* * *}$ & $11.5^{* * *}$ & $11.5^{* * *}$ & $39.6^{* * *}$ & $39.6^{* * *}$ \\
\hline
\end{tabular}

\subsection{Results by Firm Experience}

The literature suggests that new firms are vulnerable to losing their market position (Bergek et al. 2013). This is compared to the experienced firms, which can maintain their position and bear the costs of fierce competition. Therefore, Table 4 distinguishes the data as two panels: less-experienced and experienced firms. The objective was to test the importance of firm market experience in competing with the cryptocurrency market. This classification was based on the number of years the firm operated on the market. The authors took the lower quartile firms and defined them as less experienced, while the experienced firms' panel was composed of the top quartiles. The regression results in the table below show that the adverse effect of the cryptocurrency market was two-times more important for the less-experienced firms. Finally, experienced firms were more responsive to monetary and exchange rate policies.

\subsection{Results by Firm Debt Status}

Table 5 distinguishes the response of the firm market value to cryptocurrency by the firm debt status. The first panel includes the lower quartile of indebted firms, while the second one consists of the upper quartile. Consistent with the literature Sami (2021), low-debt firms had more tolerance toward external shocks relative to the high-debt ones. The results in the table below show that the negative effect of cryptocurrency was more important for the high-debt firms. Finally, firms with a high debt status were more responsive to monetary and exchange rate policies.

\subsection{Results by Illegal vs. Legal Regions}

The responses of the African countries to the cryptocurrency market were totally different. Some countries announced cryptocurrency circulation was entirely legal (e.g., South Africa), while others announced it as prohibited (e.g., Egypt). Table 6 shows that cryptocurrency had a consistent detrimental effect on businesses with these different regulations. However, in locations where cryptocurrencies have been authorized, the negative impact was two-times bigger than in countries where they have been proclaimed illegal. 
Table 4. Regression results by firm experience.

\begin{tabular}{|c|c|c|c|c|}
\hline & \multicolumn{2}{|c|}{ Less Experienced } & \multicolumn{2}{|l|}{ Experienced } \\
\hline & $\begin{array}{l}\text { PCSE } \\
\text { (1) }\end{array}$ & $\begin{array}{l}\text { DPCSE } \\
\text { (2) }\end{array}$ & $\begin{array}{l}\text { PCSE } \\
\text { (3) }\end{array}$ & $\begin{array}{l}\text { DPCSE } \\
\text { (4) }\end{array}$ \\
\hline L. (Crypt MC) & $\begin{array}{l}-0.102^{* * *} \\
(0.020)\end{array}$ & $\begin{array}{l}-0.102 * * * \\
(0.025)\end{array}$ & $\begin{array}{l}-0.046^{* * *} \\
(0.016)\end{array}$ & $\begin{array}{l}-0.046^{* * *} \\
(0.017)\end{array}$ \\
\hline Total Assets & $\begin{array}{l}0.273^{* * *} \\
(0.095)\end{array}$ & $\begin{array}{l}0.273 \text { ** } \\
(0.127)\end{array}$ & $\begin{array}{l}0.041 \\
(0.095)\end{array}$ & $\begin{array}{l}0.041 \\
(0.113)\end{array}$ \\
\hline Debt-to-Asset & $\begin{array}{l}0.005 \\
(0.039)\end{array}$ & $\begin{array}{l}0.005 \\
(0.056)\end{array}$ & $\begin{array}{l}-0.065 \\
(0.040)\end{array}$ & $\begin{array}{l}-0.065 \\
(0.041)\end{array}$ \\
\hline Profitability & $\begin{array}{l}0.136^{* * *} \\
(0.035)\end{array}$ & $\begin{array}{l}0.136^{* * *} \\
(0.051)\end{array}$ & $\begin{array}{l}0.157^{* * *} \\
(0.034)\end{array}$ & $\begin{array}{l}0.157^{* * *} \\
(0.044)\end{array}$ \\
\hline Money Growth & $\begin{array}{l}-0.008 \\
(0.012)\end{array}$ & $\begin{array}{l}-0.008 \\
(0.015)\end{array}$ & $\begin{array}{l}-0.030 * * * \\
(0.009)\end{array}$ & $\begin{array}{l}-0.030^{* * *} \\
(0.009)\end{array}$ \\
\hline Exchange Rate & $\begin{array}{l}0.001 \\
(0.001)\end{array}$ & $\begin{array}{l}0.001^{* *} \\
(0.0003)\end{array}$ & $\begin{array}{l}-0.003^{* * *} \\
(0.001)\end{array}$ & $\begin{array}{l}-0.003^{* * *} \\
(0.001)\end{array}$ \\
\hline Trade & $\begin{array}{l}-3.220 \text { ** } \\
(1.482)\end{array}$ & $\begin{array}{l}-3.220^{* *} \\
(1.424)\end{array}$ & $\begin{array}{l}-0.485 \\
(1.016)\end{array}$ & $\begin{array}{l}-0.485 \\
(1.316)\end{array}$ \\
\hline Panel FE & YES & YES & YES & YES \\
\hline Time FE & YES & YES & YES & YES \\
\hline Observations & 10,557 & 10,557 & 9360 & 9360 \\
\hline $\mathrm{R}^{2}$ & 0.106 & 0.106 & 0.151 & 0.151 \\
\hline Adjusted $\mathrm{R}^{2}$ & 0.091 & 0.091 & 0.138 & 0.138 \\
\hline F Statistic & $68.561^{* * *}$ & $68.561^{* * *}$ & $90.905^{* * *}$ & $90.905^{* * *}$ \\
\hline
\end{tabular}

Table 5. Regression results by debt status.

\begin{tabular}{lllll}
\hline & Low Debt & & High Debt & \\
\hline & PCSE & DPCSE & PCSE & DPCSE \\
& $\mathbf{( 1 )}$ & $\mathbf{( 2 )}$ & $\mathbf{( 3 )}$ & $\mathbf{( 4 )}$ \\
\hline L. (Crypt MC) & $-0.043^{* * *}$ & $-0.043^{* * *}$ & $-0.076^{* * *}$ & $-0.076^{* * *}$ \\
& $(0.015)$ & $(0.017)$ & $(0.009)$ & $(0.012)$ \\
Total Assets & 0.114 & 0.114 & $0.189^{* * *}$ & $0.189^{* * *}$ \\
& $(0.086)$ & $(0.132)$ & $(0.050)$ & $(0.072)$ \\
Debt-to-Asset & -0.144 & -0.144 & -0.022 & -0.022 \\
& $(0.137)$ & $(0.202)$ & $(0.019)$ & $(0.024)$ \\
Profitability & $0.059^{* *}$ & 0.059 & $0.104^{* * *}$ & $0.104^{* * *}$ \\
& $(0.027)$ & $(0.040)$ & $(0.017)$ & $(0.02)^{* * *}$ \\
Money Growth & -0.018 & -0.018 & $-0.019^{* * *}$ & $-0.019^{* * *}$ \\
& $(0.011)$ & $(0.013)$ & $(0.005)$ & $(0.006)$ \\
Exchange Rate & -0.001 & -0.001 & $-0.001^{* * *}$ & $-0.001^{* *}$ \\
& $(0.001)$ & $(0.001)$ & $(0.0004)$ & $(0.001)$ \\
Trade & $2.591^{* * *}$ & $2.591^{* *}$ & 0.028 & 0.028 \\
& $(0.999)$ & $(1.104)$ & $(0.575)$ & $(0.712)$ \\
\hline Panel FE & YES & YES & YES & YES \\
Time FE & YES & YES & YES & YES \\
\hline Observations & 10,108 & 10,108 & 39,217 & 39,217 \\
$R^{2}$ & 0.068 & 0.068 & 0.106 & 0.106 \\
Adjusted R ${ }^{2}$ & 0.043 & 0.043 & 0.092 & 0.092 \\
F Statistic & $39.65^{* * *}$ & $39.65^{* * *}$ & $253.34^{* * *}$ & $253.34^{* * *}$ \\
\hline
\end{tabular}

Note: clustered standard errors in parentheses. ${ }^{* * *} p<0.01,{ }^{* *} p<0.05,{ }^{*} p<0.1$. 
Table 6. Regression results by illegal vs. legal regions.

\begin{tabular}{lllll}
\hline & Illegal Regions & \multicolumn{3}{l}{ Legal Regions } \\
\hline & PCSE & DPCSE & PCSE & DPCSE \\
& $\mathbf{( 1 )}$ & $\mathbf{( 2 )}$ & $\mathbf{( 3 )}$ & $\mathbf{( 4 )}$ \\
\hline L. (Crypt MC) & $-0.031^{* *}$ & $-0.031^{* *}$ & $-0.072^{* * *}$ & $-0.072^{* * *}$ \\
& $(0.013)$ & $(0.014)$ & $(0.011)$ & $(0.016)$ \\
Total Assets & 0.060 & 0.060 & $0.312^{* * *}$ & $0.312^{* * *}$ \\
& $(0.078)$ & $(0.086)$ & $(0.061)$ & $(0.107)$ \\
Debt to Asset & $0.041^{*}$ & 0.041 & $-0.079 * * *$ & $-0.079^{* * *}$ \\
& $(0.024)$ & $(0.027)$ & $(0.025)$ & $(0.031)$ \\
Profitability & $0.094^{* * *}$ & $0.094^{* * *}$ & $0.131^{* * *}$ & $0.131^{* * *}$ \\
& $(0.022)$ & $(0.026)$ & $(0.023)$ & $(0.032)$ \\
Money Growth & $0.241^{* * *}$ & $0.241^{* * *}$ & $-0.028^{* * *}$ & $-0.028^{* * *}$ \\
& $(0.040)$ & $(0.046)$ & $(0.005)$ & $(0.006)$ \\
Exchange Rate & -0.0003 & -0.0003 & $-0.002 * * *$ & $-0.002^{* * *}$ \\
& $(0.0004)$ & $(0.0003)$ & $(0.0005)$ & $(0.001)$ \\
Trade & $2.000 * * *$ & $2.000^{* * *}$ & -0.216 & -0.216 \\
& $(0.646)$ & $(0.796)$ & $(0.945)$ & $(1.133)$ \\
\hline Panel FE & YES & YES & YES & YES \\
Time FE & YES & YES & YES & YES \\
\hline Observations & 17,947 & 17,947 & 24,444 & 24,444 \\
R $^{2}$ & 0.126 & 0.126 & 0.153 & 0.153 \\
Adjusted R & & 0.113 & 0.140 & 0.140 \\
F Statistic & 0.113 & $141.85^{* * *}$ & $241.54^{* * *}$ & $241.54 * * *$ \\
\hline No: & $141.85^{* * *}$ & & &
\end{tabular}

Note: clustered standard errors in parentheses. ${ }^{* *} p<0.01,{ }^{* *} p<0.05,{ }^{*} p<0.1$.

\section{Robustness Checks}

As a robustness check, the authors defined a binary dependent variable for the firm's stock market cap. This variable takes one if the stock market cap of the firm is greater than the average stock market cap of the sector in which it operates or zero otherwise. Robustness regressions consider the properties of the logit model as the main estimation strategy. This section tests whether the previous findings will remain robust if the authors change the dependent variable structure and the econometric methodology while maintaining the clustered standard errors' condition. The marginal effects of the logit model are presented in Appendix A.

\subsection{Robustness by Firm Sector}

Table 7 presents the main logit model results across the six main sectors. The marginal effects are shown in Table A3 and are consistent with the previous findings. The cryptocurrency market seemed to have the most significant effect on the energy sector. Real estate and IT were not significantly affected, as previously found. For the firms operating in the energy sector, the probability that the firms' stock market cap decreased below the sector market cap average was 0.4 for each $10 \%$ increase in the cryptocurrency market cap.

\subsection{Robustness by Firm Experience}

Table 8 shows that less-experienced firms were adversely affected by the cryptocurrency market more than the experienced ones. For instance, the probability that the firms stock market decreased below the sector's average was 0.19 for each $10 \%$ increase in the cryptocurrency market cap (see Table A4). 
Table 7. Logit model by sector.

\begin{tabular}{|c|c|c|c|c|c|c|}
\hline & $\begin{array}{c}\text { Energy } \\
\text { (1) }\end{array}$ & $\begin{array}{c}\text { Financial } \\
\text { (2) }\end{array}$ & $\begin{array}{c}\text { Industrial } \\
\text { (3) }\end{array}$ & $\begin{array}{c}\text { Consumer } \\
\text { Services } \\
\text { (4) }\end{array}$ & $\begin{array}{l}\text { IT } \\
\text { (5) }\end{array}$ & $\begin{array}{c}\text { Real } \\
\text { Estate } \\
(6)\end{array}$ \\
\hline Crypt MC & $\begin{array}{l}-0.327^{* * *} \\
(0.026)\end{array}$ & $\begin{array}{l}-0.116^{* * *} \\
(0.037)\end{array}$ & $\begin{array}{l}-0.129 * \\
(0.071)\end{array}$ & $\begin{array}{l}-0.135^{* * *} \\
(0.042)\end{array}$ & $\begin{array}{l}0.124 \\
(0.125)\end{array}$ & $\begin{array}{l}0.013 \\
(0.072)\end{array}$ \\
\hline Total Assets & $\begin{array}{l}1.738^{* * *} \\
(0.601)\end{array}$ & $\begin{array}{l}0.526 * * * \\
(0.136)\end{array}$ & $\begin{array}{l}0.388 * * \\
(0.181)\end{array}$ & $\begin{array}{l}0.593^{* * *} \\
(0.192)\end{array}$ & $\begin{array}{l}0.189 \\
(0.221)\end{array}$ & $\begin{array}{l}0.697 * * \\
(0.286)\end{array}$ \\
\hline Debt-to-Asset & $\begin{array}{l}-1.172 \\
(0.838)\end{array}$ & $\begin{array}{l}0.011 \\
(0.164)\end{array}$ & $\begin{array}{l}0.190 \\
(0.204)\end{array}$ & $\begin{array}{l}0.014 \\
(0.130)\end{array}$ & $\begin{array}{l}0.143 \\
(0.241)\end{array}$ & $\begin{array}{l}-0.091 \\
(0.235)\end{array}$ \\
\hline Profitability & $\begin{array}{l}0.888 * * \\
(0.411)\end{array}$ & $\begin{array}{l}-0.108 \\
(0.186)\end{array}$ & $\begin{array}{l}0.436 \\
(0.342)\end{array}$ & $\begin{array}{l}0.451 * * \\
(0.219)\end{array}$ & $\begin{array}{l}-0.602 \\
(0.275)\end{array}$ & $\begin{array}{l}1.138^{* * *} \\
(0.334)\end{array}$ \\
\hline Money Growth & $\begin{array}{l}0.134 \\
(0.149)\end{array}$ & $\begin{array}{l}-0.034 \\
(0.035)\end{array}$ & $\begin{array}{l}0.006 \\
(0.034)\end{array}$ & $\begin{array}{l}-0.016 \\
(0.032)\end{array}$ & $\begin{array}{l}-0.189 * * * \\
(0.047)\end{array}$ & $\begin{array}{l}0.029 \\
(0.061)\end{array}$ \\
\hline Exchange Rate & $\begin{array}{l}-0.003 \\
(0.003)\end{array}$ & $\begin{array}{l}-0.003 \\
(0.003)\end{array}$ & $\begin{array}{l}-0.090 \\
(0.081)\end{array}$ & $\begin{array}{l}0.002 * * * \\
(0.001)\end{array}$ & $\begin{array}{l}-0.012 \\
(0.008)\end{array}$ & $\begin{array}{l}-0.002 \\
(0.013)\end{array}$ \\
\hline Trade & $\begin{array}{l}-20.140^{* * *} \\
(2.957)\end{array}$ & $\begin{array}{l}-1.322 \\
(4.075)\end{array}$ & $\begin{array}{l}-6.957 \\
(5.847)\end{array}$ & $\begin{array}{l}-8.775 \\
(5.836)\end{array}$ & $\begin{array}{l}-6.649 \\
(9.784)\end{array}$ & $\begin{array}{l}-4.984 \\
(11.813)\end{array}$ \\
\hline Panel FE & YES & YES & YES & YES & YES & YES \\
\hline Time FE & YES & YES & YES & YES & YES & YES \\
\hline Observations & 1642 & 12,858 & 5960 & 13,426 & 2,180 & 5868 \\
\hline Wald Chi ${ }^{2}$ & $884^{* * *}$ & $2879 * * *$ & $859^{* * *}$ & $2532^{* * *}$ & $394^{* * *}$ & $1786^{* * *}$ \\
\hline Pseudo $\mathrm{R}^{2}$ & 0.421 & 0.227 & 0.151 & 0.189 & 0.1421 & 0.34 \\
\hline Log Likelihood & -607.7 & -4888 & -2435 & -5425 & -1190 & -1728 \\
\hline
\end{tabular}

Table 8. Logit model results by firm experience.

\begin{tabular}{|c|c|c|}
\hline & $\begin{array}{l}\text { Less Experienced } \\
\text { (1) }\end{array}$ & $\begin{array}{l}\text { Experienced } \\
(2)\end{array}$ \\
\hline Crypt MC & $\begin{array}{l}-0.091^{* *} \\
(0.046)\end{array}$ & $\begin{array}{l}-0.038 \\
(0.036)\end{array}$ \\
\hline Total Assets & $\begin{array}{l}0.486^{* * *} \\
(0.111)\end{array}$ & $\begin{array}{l}0.441^{* * *} \\
(0.095)\end{array}$ \\
\hline Debt-to-Asset & $\begin{array}{l}-0.052 \\
(0.113)\end{array}$ & $\begin{array}{l}0.029 \\
(0.102)\end{array}$ \\
\hline Profitability & $\begin{array}{l}-0.165 \\
(0.134)\end{array}$ & $\begin{array}{l}0.189 * \\
(0.112)\end{array}$ \\
\hline Money Growth & $\begin{array}{l}0.027 \\
(0.032)\end{array}$ & $\begin{array}{l}0.002 \\
(0.030)\end{array}$ \\
\hline Exchange Rate & $\begin{array}{l}-0.000 \\
(0.001)\end{array}$ & $\begin{array}{l}-0.001 \\
(0.001)\end{array}$ \\
\hline Trade & $\begin{array}{l}-17.870 * * * \\
(6.721)\end{array}$ & $\begin{array}{l}-7.307 * \\
(4.207)\end{array}$ \\
\hline $\begin{array}{l}\text { Panel FE } \\
\text { Time FE }\end{array}$ & $\begin{array}{l}\text { YES } \\
\text { YES }\end{array}$ & $\begin{array}{l}\text { YES } \\
\text { YES }\end{array}$ \\
\hline $\begin{array}{l}\text { Observations } \\
\text { Wald Chi }^{2} \\
\text { Pseudo } \mathrm{R}^{2} \\
\text { Log Likelihood }\end{array}$ & $\begin{array}{l}9878 \\
58.54^{* * *} \\
0.140 \\
-5839\end{array}$ & $\begin{array}{l}13,590 \\
44.94^{* * *} \\
0.144 \\
-7916\end{array}$ \\
\hline
\end{tabular}

Note: clustered standard errors in parentheses. ${ }^{* * *} p<0.01,{ }^{* *} p<0.05,{ }^{*} p<0.1$.

\subsection{Robustness by Firm Debt Status}

For robustness related to the firm debt status results, Table 9 below shows that the cryptocurrency market significantly affected high-debt firms. This finding supports our previous results in Table 5 . 
Table 9. Logit model by firm debt status.

\begin{tabular}{|c|c|c|}
\hline & $\begin{array}{l}\text { Low Debt } \\
\text { (1) }\end{array}$ & $\begin{array}{l}\text { High Debt } \\
\text { (2) }\end{array}$ \\
\hline Crypt MC & $\begin{array}{l}-0.122^{* * *} \\
(0.044)\end{array}$ & $\begin{array}{l}-0.157^{* * *} \\
(0.048)\end{array}$ \\
\hline Total Assets & $\begin{array}{l}0.458 * * * \\
(0.116)\end{array}$ & $\begin{array}{l}0.517 * * * \\
(0.102)\end{array}$ \\
\hline Debt-to-Asset & $\begin{array}{l}-0.423 \\
(0.520)\end{array}$ & $\begin{array}{l}-0.165 \\
(0.477)\end{array}$ \\
\hline Profitability & $\begin{array}{l}0.112 \\
(0.126)\end{array}$ & $\begin{array}{l}0.209 * \\
(0.127)\end{array}$ \\
\hline Money Growth & $\begin{array}{l}0.017 \\
(0.045)\end{array}$ & $\begin{array}{l}0.056 \\
(0.039)\end{array}$ \\
\hline Exchange Rate & $\begin{array}{l}0.000 \\
(0.000)\end{array}$ & $\begin{array}{l}-0.000 \\
(0.001)\end{array}$ \\
\hline Trade & $\begin{array}{l}-13.973^{* * *} \\
(5.125)\end{array}$ & $\begin{array}{l}-3.171 \\
(5.110)\end{array}$ \\
\hline $\begin{array}{l}\text { Panel FE } \\
\text { Time FE }\end{array}$ & $\begin{array}{l}\text { YES } \\
\text { YES }\end{array}$ & $\begin{array}{l}\text { YES } \\
\text { YES }\end{array}$ \\
\hline $\begin{array}{l}\text { Observations } \\
\text { Wald Chi }{ }^{2} \\
\text { Pseudo R }{ }^{2} \\
\text { Log Likelihood }\end{array}$ & $\begin{array}{l}10,313 \\
76.38^{* * *} \\
0.155 \\
-5980\end{array}$ & $\begin{array}{l}9430 \\
50.04 * * * \\
0.146 \\
-5577\end{array}$ \\
\hline
\end{tabular}

Note: clustered standard errors in parentheses. ${ }^{* *} p<0.01,{ }^{* *} p<0.05,{ }^{*} p<0.1$.

\subsection{Logit Results by Illegal vs. Legal Regions}

Table 10 tests the robustness of the African government policies dealing with the cryptocurrency market. As previously estimated, the regions that banned cryptocurrency transactions failed in protecting their domestic firms. The cryptocurrency market had a consistent detrimental effect on businesses, implying that these regulations are inefficient.

Table 10. Logit model by legal vs. illegal regions.

\begin{tabular}{|c|c|c|}
\hline & $\begin{array}{l}\text { Illegal } \\
\text { (1) }\end{array}$ & $\begin{array}{l}\text { Legal } \\
(2)\end{array}$ \\
\hline Crypto MC & $\begin{array}{l}-0.070 * * \\
(0.029)\end{array}$ & $\begin{array}{l}-0.035 * \\
(0.019)\end{array}$ \\
\hline Debt-to-Asset & $\begin{array}{l}0.000 \\
(0.005)\end{array}$ & $\begin{array}{l}-0.002 \\
(0.002)\end{array}$ \\
\hline Log (Total Assets) & $\begin{array}{l}0.286^{* * *} \\
(0.091)\end{array}$ & $\begin{array}{l}0.095^{* * *} \\
(0.023)\end{array}$ \\
\hline Foreign Ownership Index & $\begin{array}{l}0.200 * * \\
(0.081)\end{array}$ & $\begin{array}{l}-0.163 \\
(0.100)\end{array}$ \\
\hline Trade Barriers Index & $\begin{array}{l}0.209 * * \\
(0.087)\end{array}$ & $\begin{array}{l}0.060 \\
(0.104)\end{array}$ \\
\hline TFP & $\begin{array}{l}0.020 \\
(0.506)\end{array}$ & $\begin{array}{l}-3.321 \\
(1.554)\end{array}$ \\
\hline Money Growth & $\begin{array}{l}-0.179 \\
(0.131)\end{array}$ & $\begin{array}{l}0.064 \\
(0.082)\end{array}$ \\
\hline Exchange Rate & $\begin{array}{l}-0.000 \\
(0.001)\end{array}$ & $\begin{array}{l}0.000 \\
(0.001)\end{array}$ \\
\hline Constant & $\begin{array}{l}-2.842 \text { ** } \\
(1.409)\end{array}$ & $\begin{array}{l}1.006 \\
(0.874)\end{array}$ \\
\hline $\begin{array}{l}\text { Region FE } \\
\text { Time FE }\end{array}$ & $\begin{array}{l}\text { YES } \\
\text { YES }\end{array}$ & $\begin{array}{l}\text { YES } \\
\text { YES }\end{array}$ \\
\hline $\begin{array}{l}\text { Pseudo R2 } \\
\text { Wald Statistic } \\
\text { Observations }\end{array}$ & $\begin{array}{l}0.10 \\
40.1^{* * *} \\
24,348\end{array}$ & $\begin{array}{l}0.08 \\
70.5^{* * *} \\
35,559\end{array}$ \\
\hline
\end{tabular}

Note: clustered standard errors in parentheses. ${ }^{* * *} p<0.01,{ }^{* *} p<0.05,{ }^{*} p<0.1$. 


\section{Conclusions}

The world is flat (Friedman 2005). Cryptocurrency affects micro-entities (i.e., firms) along with the main macroeconomic and financial indexes. In the case of Africa, each 10\% growth in the cryptocurrency market cap reduced the market value of African firms by $0.76 \%$.

The study showed that firms in less-competitive sectors (i.e., those more vulnerable to losses) are more likely to be hurt by the cryptocurrency market's expansion. For instance, the cryptocurrency market has a considerable effect on Africa's energy, financial, industrial, and consumer services sectors, while real estate and information technology are not significantly affected. Conspicuously, African firms are forced to undergo a novel competition to face the cryptocurrency market. The study highlighted the importance of firm experience and the internal strategies to have a competitive position in this new market (Montout and Sami 2016; Sami and Eldomiaty 2020; Sami and Abdallah 2021).

In terms of policy-making, it is worth noting that countries that have banned cryptocurrencies have failed to protect their domestic firms. This fact calls for government interventions to improve the financial market's competitiveness in Africa. In this context, the authors suggest the following policy initiatives. Firstly, the African governments should raise the competitiveness of their stock markets. This requires (1) boosting innovations and improving regulations in this traditional financial market to compete with the cryptocurrency market. (2) Governments should foster the diversity of stocks in Africa. The stock market cap in Africa is considerably large; however, it suffers from limited stocks. (3) It is time to address financial services and infrastructural challenges in Africa, which have become an obvious impediment to the development and competitiveness of the stock market. Furthermore, many African stocks have inadequate disclosures, which adversely affects the investors' decisions. This severe problem affects the African firms' performance, value, and reputation, especially when compared to the cryptocurrency market context and environment. Besides, the listed firms in Africa are invited to assess the effectiveness of their internal controls in dealing with these deficiency disclosures.

Secondly, severe competition has characterized this decade, implying that only the most productive firms will survive and thrive. Firms should strengthen their strategies to attract investors, as shown in the real estate and information technology sectors. This fact highlights the role of firm productivity, performance, and innovations.

Thirdly, the Development Financial Institutions (DFIs) play a major role in supporting the listed companies in Africa (Triki and Faye 2013). For instance, DFIs should prioritize their investments in countries, industries, or business areas that private investors perceive as costly and risky. DFIs have failed to create a standardized complete transparent reporting system for their initiatives. Statistics on DFI activities are critical for tracking financial inclusion growth, evaluating DFI accomplishments, and identifying important intervention needs. DFIs should concentrate their efforts even more on Africa, where only a small percentage of the population has a formal bank account and where firms face considerable financial restrictions.

Finally, African investors are likely to realize substantial capital gains from the cryptocurrency market. Therefore, the African governments need to expedite the aforementioned financial system adjustments to reap the benefit from these capital gains and attract them for long-term investments in Africa.

Author Contributions: M.S. and W.A. contributed equally to this work. All authors have read and agreed to the published version of the manuscript.

Funding: This research was funded by the School of Business resarch grant, approved on 25 October 2021.

Conflicts of Interest: The authors declare no conflict of interest. 


\section{Appendix A}

Table A1. Descriptive statistics.

\begin{tabular}{|c|c|c|c|c|c|c|c|c|}
\hline Stats & Stock MC & Crypt MC & $\begin{array}{r}\text { Total } \\
\text { Assets }\end{array}$ & $\begin{array}{l}\text { Debt- } \\
\text { to-Asset }\end{array}$ & Profitability & $\begin{array}{l}\text { Money } \\
\text { Growth }\end{array}$ & $\begin{array}{r}\text { Exchange } \\
\text { Rate }\end{array}$ & Trade \\
\hline Mean & 11.68 & 24.14 & 15.54 & 2.20 & 2.42 & 7.66 & 74.59 & 0.02 \\
\hline SD & 2.18 & 1.84 & 2.55 & 1.40 & 1.03 & 2.74 & 301.10 & 0.05 \\
\hline Min & 3.22 & 20.81 & 8.34 & 0.00 & -4.61 & 0.00 & 0.00 & -0.14 \\
\hline Max & 18.48 & 27.73 & 23.01 & 5.36 & 9.55 & 9.95 & 3727.07 & 0.11 \\
\hline Skewness & 0.03 & -0.05 & 0.23 & -0.42 & -0.64 & -2.04 & 10.30 & -0.52 \\
\hline Kurtosis & 2.85 & 1.53 & 2.83 & 1.85 & 6.13 & 6.08 & 116.84 & 3.24 \\
\hline
\end{tabular}

Table A2. Correlation matrix.

\begin{tabular}{|c|c|c|c|c|c|c|c|}
\hline & Crypt MC & $\begin{array}{r}\text { Total } \\
\text { Assets }\end{array}$ & $\begin{array}{l}\text { Debt- } \\
\text { to-Asset }\end{array}$ & Profitability & $\begin{array}{l}\text { Money } \\
\text { Growth }\end{array}$ & $\begin{array}{l}\text { Exchange } \\
\text { Rate }\end{array}$ & Trade \\
\hline Crypt MC & 1.00 & & & & & & \\
\hline Total Assets & 0.07 & 1.00 & & & & & \\
\hline Debt-to-Asset & 0.02 & 0.16 & 1.00 & & & & \\
\hline Profitability & 0.00 & 0.11 & -0.15 & 1.00 & & & \\
\hline Money Growth & 0.19 & 0.01 & 0.00 & -0.01 & 1.00 & & \\
\hline Exchange Rate & 0.03 & 0.28 & -0.01 & 0.01 & 0.05 & 1.00 & \\
\hline Trade & -0.03 & -0.32 & 0.00 & 0.08 & 0.02 & -0.17 & 1.00 \\
\hline
\end{tabular}

Table A3. Marginal effects logit model by sector.

\begin{tabular}{|c|c|c|c|c|c|c|}
\hline & $\begin{array}{c}\text { Energy } \\
\text { (1) }\end{array}$ & $\begin{array}{c}\text { Financial } \\
\text { (2) }\end{array}$ & $\begin{array}{c}\text { Industrial } \\
\text { (3) }\end{array}$ & $\begin{array}{c}\text { Consumer } \\
\text { Services } \\
\text { (4) }\end{array}$ & $\begin{array}{l}\text { IT } \\
\text { (5) }\end{array}$ & $\begin{array}{c}\text { Real } \\
\text { Estate } \\
(6)\end{array}$ \\
\hline Crypt MC & $\begin{array}{l}-0.040^{* * *} \\
(0.002)\end{array}$ & $\begin{array}{l}-0.014^{\text {*** }} \\
(0.005)\end{array}$ & $\begin{array}{l}-0.017 \text { * } \\
(0.009)\end{array}$ & $\begin{array}{l}-0.017^{\text {*** }} \\
(0.005)\end{array}$ & $\begin{array}{l}0.023 \\
(0.023)\end{array}$ & $\begin{array}{l}0.001 \\
(0.007)\end{array}$ \\
\hline Total Assets & $\begin{array}{l}0.211^{* * *} \\
(0.058)\end{array}$ & $\begin{array}{l}0.063^{* * *} \\
(0.013)\end{array}$ & $\begin{array}{l}0.050 * * \\
(0.019)\end{array}$ & $\begin{array}{l}0.076^{* * *} \\
(0.020)\end{array}$ & $\begin{array}{l}0.035 \\
(0.039)\end{array}$ & $\begin{array}{l}0.064^{* * *} \\
(0.019)\end{array}$ \\
\hline Debt-to-Asset & $\begin{array}{l}-0.142 \\
(0.095)\end{array}$ & $\begin{array}{l}0.001 \\
(0.020)\end{array}$ & $\begin{array}{l}0.024 \\
(0.027)\end{array}$ & $\begin{array}{l}0.002 \\
(0.017)\end{array}$ & $\begin{array}{l}0.026 \\
(0.044)\end{array}$ & $\begin{array}{l}-0.008 \\
(0.021)\end{array}$ \\
\hline Profitability & $\begin{array}{l}0.108^{*} \\
(0.051)\end{array}$ & $\begin{array}{l}-0.013 \\
(0.022)\end{array}$ & $\begin{array}{l}0.056 \\
(0.041)\end{array}$ & $\begin{array}{l}0.058^{* *} \\
(0.027)\end{array}$ & $\begin{array}{l}-0.110 \text { ** } \\
(0.050)\end{array}$ & $\begin{array}{l}0.104^{* * *} \\
(0.027)\end{array}$ \\
\hline Money Growth & $\begin{array}{l}0.016 \\
(0.018)\end{array}$ & $\begin{array}{l}-0.004 \\
(0.004)\end{array}$ & $\begin{array}{l}0.001 \\
(0.004)\end{array}$ & $\begin{array}{l}-0.002 \\
(0.004)\end{array}$ & $\begin{array}{l}-0.035^{* * *} \\
(0.009)\end{array}$ & $\begin{array}{l}0.003 \\
(0.006)\end{array}$ \\
\hline Exchange Rate & $\begin{array}{l}-0.000 \\
(0.000)\end{array}$ & $\begin{array}{l}-0.000 \\
(0.000)\end{array}$ & $\begin{array}{l}-0.012 \\
(0.010)\end{array}$ & $\begin{array}{l}0.000^{* * *} \\
(0.000)\end{array}$ & $\begin{array}{l}-0.002 \\
(0.001)\end{array}$ & $\begin{array}{l}-0.000 \\
(0.001)\end{array}$ \\
\hline Trade & $\begin{array}{l}-2.447^{* * *} \\
(2.957)\end{array}$ & $\begin{array}{l}-0.158 \\
(4.075)\end{array}$ & $\begin{array}{l}-0.895 \\
(5.847)\end{array}$ & $\begin{array}{l}-1.130 \\
(5.836)\end{array}$ & $\begin{array}{l}-1.218 \\
(9.784)\end{array}$ & $\begin{array}{c}-0.455 \\
(11.813)\end{array}$ \\
\hline Panel FE & YES & YES & YES & YES & YES & YES \\
\hline Time FE & YES & YES & YES & YES & YES & YES \\
\hline Observations & 1642 & 12,858 & 5960 & 13,426 & 2180 & 5868 \\
\hline Wald $\mathrm{Chi}^{2}$ & $884^{* * *}$ & $2879 * * *$ & $859 * * *$ & $2532 * * *$ & $394 * * *$ & $1786^{* * *}$ \\
\hline Pseudo $R^{2}$ & 0.421 & 0.227 & 0.151 & 0.189 & 0.1421 & 0.34 \\
\hline Log Likelihood & -607.7 & -4888 & -2435 & -5425 & -1190 & -1728 \\
\hline
\end{tabular}


Table A4. Marginal effects logit model by firm experience.

\begin{tabular}{|c|c|c|}
\hline & $\begin{array}{l}\text { Less Experienced } \\
\text { (1) }\end{array}$ & $\begin{array}{l}\text { Experienced } \\
\text { (2) }\end{array}$ \\
\hline L. (Crypt MC) & $\begin{array}{l}-0.019^{* *} \\
(0.009)\end{array}$ & $\begin{array}{l}-0.008 \\
(0.007)\end{array}$ \\
\hline Total Assets & $\begin{array}{l}0.099^{* * *} \\
(0.017)\end{array}$ & $\begin{array}{l}0.088^{* * *} \\
(0.014)\end{array}$ \\
\hline Debt-to-Asset & $\begin{array}{l}-0.011 \\
(0.023)\end{array}$ & $\begin{array}{l}0.006 \\
(0.020)\end{array}$ \\
\hline Profitability & $\begin{array}{l}-0.034 \\
(0.027)\end{array}$ & $\begin{array}{l}0.038^{*} \\
(0.022)\end{array}$ \\
\hline Money Growth & $\begin{array}{l}0.005 \\
(0.007)\end{array}$ & $\begin{array}{l}0.000 \\
(0.006)\end{array}$ \\
\hline Exchange Rate & $\begin{array}{l}-0.000 \\
(0.000)\end{array}$ & $\begin{array}{l}-0.000 \\
(0.000)\end{array}$ \\
\hline Trade & $\begin{array}{l}-17.870 * * * \\
(6.721)\end{array}$ & $\begin{array}{l}-7.307 * \\
(4.207)\end{array}$ \\
\hline Panel FE & YES & YES \\
\hline Time FE & YES & YES \\
\hline Observations & 9878 & 13,590 \\
\hline Wald $\mathrm{Chi}^{2}$ & $58.54^{* * *}$ & $44.94^{* * *}$ \\
\hline Pseudo $\mathrm{R}^{2}$ & 0.140 & 0.144 \\
\hline Log Likelihood & -5839 & -7916 \\
\hline
\end{tabular}

Table A5. Marginal effect of the logit model by firm debt status.

\begin{tabular}{lll}
\hline & $\begin{array}{l}\text { Low Debt } \\
(\mathbf{1})\end{array}$ & $\begin{array}{l}\text { High Debt } \\
\mathbf{( 2 )}\end{array}$ \\
\hline Crypt MC & $-0.024^{* * *}$ & $-0.032^{* * *}$ \\
& $(0.008)$ & $(0.009)$ \\
Total Assets & $0.091^{* * *}$ & $0.105^{* * *}$ \\
& $(0.018)$ & $(0.015)$ \\
Debt-to-Asset & -0.084 & -0.034 \\
& $(0.102)$ & $(0.097)$ \\
Profitability & 0.022 & $0.042^{*}$ \\
& $(0.025)$ & $(0.026)$ \\
Money Growth & 0.003 & 0.011 \\
& $(0.009)$ & $(0.008)$ \\
Exchange Rate & 0.000 & -0.000 \\
Trade & $(0.000)$ & $(0.000)$ \\
& $-2.770^{* * *}$ & -0.643 \\
Panel FE & $(1.064)$ & $(1.039)$ \\
Time FE & YES & YES \\
\hline Observations & YES & YES \\
Wald Chi ${ }^{2}$ & 10,313 & 9430 \\
Pseudo R & $76.38^{* * *}$ & $50.04 * * *$ \\
Log Likelihood & 0.155 & 0.146 \\
\hline Note: clustered standard errors in parentheses. & -5980 & -5577 \\
\hline
\end{tabular}


Table A6. Marginal effect of the logit model by illegal vs. legal regions.

\begin{tabular}{lll}
\hline & $\begin{array}{l}\text { Illegal } \\
(\mathbf{1})\end{array}$ & $\begin{array}{l}\text { Legal } \\
\mathbf{( 2 )}\end{array}$ \\
\hline Crypt MC & $-0.018^{* * * *}$ & $-0.012^{* *}$ \\
& $(0.007)$ & $(0.005)$ \\
Total Assets & $0.131^{* * *}$ & $0.072^{* * *}$ \\
& $(0.009)$ & $(0.011)$ \\
Debt-to-Asset & $-0.025^{*}$ & 0.005 \\
& $(0.014)$ & $(0.016)$ \\
Profitability & 0.013 & 0.022 \\
& $(0.019)$ & $(0.019)$ \\
Money Growth & 0.008 & 0.001 \\
& $(0.014)$ & $(0.003)$ \\
Exchange Rate & -0.000 & 0.000 \\
& $(0.000)$ & $(0.000)$ \\
Trade & 0.389 & 0.650 \\
& $(0.424)$ & $(0.701)$ \\
\hline Panel FE & YES & YES \\
Time FE & YES & YES \\
\hline Observations & 10,313 & 9430 \\
Wald Chi ${ }^{2}$ & $76.38^{* * *}$ & $50.044^{* * *}$ \\
Pseudo R & 0.155 & 0.146 \\
Log Likelihood & -5980 & -5577 \\
\hline Note: clustered standard errors in parentheses. ${ }^{* * *} p<0.01,^{* *} p<0.05,^{*} p<0.1$. &
\end{tabular}

\section{Notes}

1 Over the last decade, the stock market in the energy, financial, and industrial sectors declined by $75 \%$, 48\%, and $9 \%$ in Africa. For instance, real estate and information technology realized $100 \%$ and $77 \%$, respectively, according to the MSCI ACWI Investable Market Index (2021).

2 For further details, see the MSCI ACWI Investable Market Index (2021).

\section{References}

Agbo, Elias Igwebuike, and Eugene O. Nwadialor. 2020. Cryptocurrency and the african economy. Economics And Social Sciences Academic Journal 2: 84-100.

Baggs, Jen, Eugene Beaulieu, and Loretta Fung. 2009. Firm survival, performance, and the exchange rate. The Canadian Journal of Economics / Revue canadienne d'Economique 42: 393-421. [CrossRef]

Baumöhl, Eduard. 2019. Are cryptocurrencies connected to forex? A quantile cross-spectral approach. Finance Research Letters 29: 363-72. [CrossRef]

Beck, Nathaniel, and Jonathan N. Katz. 1995. What to do (and not to do) with time-series cross-section data. The American Political Science Review 89: 634-47. [CrossRef]

Bergek, Anna, Christian Berggren, Thomas Magnusson, and Michael Hobday. 2013. Technological discontinuities and the challenge for incumbent firms: Destruction, disruption or creative accumulation? Research Policy 42: 1210-24. [CrossRef]

Bermudez Delgado, Nancy, Estefanía Bermudez Delgado, and Eduardo Saucedo. 2018. The relationship between oil prices, the stock market and the exchange rate: Evidence from mexico. The North American Journal of Economics and Finance 45: 266-75. [CrossRef]

Bouri, Elie, Mahamitra Das, Rangan Gupta, and David Roubaud. 2018. Spillovers between bitcoin and other assets during bear and bull markets. Applied Economics 50: 5935-49. [CrossRef]

Cameron, A. Colin, Jonah B. Gelbach, and Douglas L. Miller. 2011. Robust inference with multiway clustering. Journal of Business $\mathcal{E}$ Economic Statistics 29: 238-49.

ChainAnalsysis. 2020. The 2020 Geography of Cryptocurrency Report. Technical Report. Available online: https://go.chainalysis. com/2021-geography-of-crypto.html (accessed on 1 January 2021).

Christiano, Lawrence, Roberto Motto, Massimo Rostagno, and Cosmin Ilut. 2008. Monetary Policy and Stock Market Boom-Bust Cycles. Working paper, Series 955, European Central Bank, Frankfurt, Germany.

Corbet, Shaen, Brian Lucey, and Larisa Yarovaya. 2018. Datestamping the bitcoin and ethereum bubbles. Finance Research Letters 26: 81-88. [CrossRef]

Corbet, Shaen, Charles Larkin, Brian Lucey, and Larisa Yarovaya. 2020. Kodakcoin: A blockchain revolution or exploiting a potential cryptocurrency bubble? Applied Economics Letters 27: 518-24. [CrossRef] 
Corbet, Shaen, Yang (Greg) Hou, Yang Hu, Charles Larkin, Brian Lucey, and Les Oxley. 2021. Cryptocurrency liquidity and volatility interrelationships during the COVID-19 pandemic. Finance Research Letters 45: 102137. [CrossRef] [PubMed]

Culjak, Maria, Bojan Tomić, and Saša Žiković. 2022. Benefits of sectoral cryptocurrency portfolio optimization. Research in International Business and Finance 60: 101615. [CrossRef]

Dang, Chongyu, Zhichuan Frank Li, and Chen Yang. 2018. Measuring firm size in empirical corporate finance. Journal of Banking $\mathcal{E}$ Finance 86: 159-76.

Doumenis, Yianni, Javad Izadi, Pradeep Dhamdhere, Epameinondas Katsikas, and Dimitrios Koufopoulos. 2021. A critical analysis of volatility surprise in bitcoin cryptocurrency and other financial assets. Risks 9: 207. [CrossRef]

Dyhrberg, Anne Haubo. 2016. Bitcoin, gold and the dollar - a garch volatility analysis. Finance Research Letters 16: 85-92. [CrossRef]

Friedman, Thomas. 2005. The World is Flat: A Brief History of the Twenty-First Century. New York: Farrar, Straus and Giroux.

Gil-Alana, Luis Alberiko, Emmanuel Joel Aikins Abakah, and María Fátima Romero Rojo. 2020. Cryptocurrencies and stock market indices. are they related? Research in International Business and Finance 51: 101063. [CrossRef]

Global-Economy. 2020. Listed Companies in Africa. Atlanta: Global-Economy.

Jareño, Francisco, María de la O González, Marta Tolentino, and Karen Sierra. 2020. Bitcoin and gold price returns: A quantile regression and nardl analysis. Resources Policy 67: 101666. [CrossRef]

Kostika, Eleftheria, and Nikiforos T. Laopodis. 2019. Dynamic linkages among cryptocurrencies, exchange rates and global equity markets. Studies in Economics and Finance 2: 243-65. [CrossRef]

Masie, Desné. 2021. The Outlook for Crypto and Blockchain in Africa. African Business, December 13.

Matkovskyy, Roman, and Akanksha Jalan. 2019. From financial markets to bitcoin markets: A fresh look at the contagion effect. Finance Research Letters 31: 93-97. [CrossRef]

Mazambani, Last, and Emmanuel Mutambara. 2020. Predicting fintech innovation adoption in south africa: The case of cryptocurrency. African Journal of Economic and Management Studies 11: 30-50. [CrossRef]

Montout, Sulyie, and Mina Sami. 2016. Determinants for locating research and development activity in europe. International Economics 145: 7-20. [CrossRef]

Möykkynen, Henry, and Aristeidis Pantelias. 2021. Viability gap funding for promoting private infrastructure investment in africa: views from stakeholders. Journal of Economic Policy Reform 24: 253-69. [CrossRef]

Petukhina, Alla, Simon Trimborn, Wolfgang Karl Härdle, and Hermann Elendner. 2021. Investing with cryptocurrencies-Evaluating their potential for portfolio allocation strategies. Quantitative Finance 21: 1825-53. [CrossRef]

Rudolf, Karl Oton, Samer Ajour El Zein, and Nicola Jackman Lansdowne. 2021. Bitcoin as an investment and hedge alternative. A DCC MGARCH model analysis. Risks 9: 154. [CrossRef]

Said, Mona, Rami Galal, and Mina Sami. 2018. Gender Diversity, Productivity, and Wages in Egyptian Firms. ERF Working papers, No. 5. Cairo: Economic Research Forum (ERF).

Said, Mona, Rami Galal, and Mina Sami. 2019. Inequality And Income Mobility in Egypt. ERF Working papers, No. 1368. Cairo: ERF.

Sami, Mina. 2021. French firms and COVID-19: Do the debt status, crisis management system, and monetary policy play a role? Journal of Economics and Statistics 241: 349-72.

Sami, Mina, and Randa ElBedawy. 2019. Assessing the impact of knowledge management on total factor productivity. African Journal of Economic and Management Studies 11: 134-46. [CrossRef]

Sami, Mina, and Tarek Eldomiaty. 2020. Modeling dynamic location expansion of multinational firms in france. Empirical Economics 59: 3033-61. [CrossRef]

Sami, Mina, Tarek Eldomiaty, and Mina Kamal. 2020. How do fund rates affect the us firms? A threshold estimation. Central Bank Review 20: 75-84. [CrossRef]

Sami, Mina, and Wael Abdallah. 2020a. Cryptocurrency and stock market: Complements or substitutes? Evidence from gulf countries. Applied Finance Letters 9: 25-35. [CrossRef]

Sami, Mina, and Wael Abdallah. 2020b. How does the cryptocurrency market affect the stock market performance in the mena region? Journal of Economic and Administrative Sciences 37: 741-53. [CrossRef]

Sami, Mina, and Wael Abdallah. 2021. Assessing the impact of dividend policy on the sustainability of distressed firms. Journal of Modelling in Management 16: 987-1001. [CrossRef]

Thompson, Samuel B. 2011. Simple formulas for standard errors that cluster by both firm and time. Journal of Financial Economics 99: 1-10. [CrossRef]

Trabelsi, Nader. 2018. Are there any volatility spill-over effects among cryptocurrencies and widely traded asset classes? Journal of Risk and Financial Management 11: 1-17. [CrossRef]

Triki, Thouraya, and Issa Faye. 2013. Financial inclusion in africa. African Business, April, 2013.

TripleA. 2021. Global Crypto Adoption. Available online: https://triple-a.io/crypto-ownership/ (accessed on 1 January 2021).

White, Halbert. 1980. A heteroskedasticity-consistent covariance matrix estimator and a direct test for heteroskedasticity. Econometrica 48: 817-38. [CrossRef]

Yang, Lori. 2020. The influence of taiwan's stock market on bitcoin's price under taiwan's monetary policy threshold. Applied Economics 52: 4967-75. [CrossRef]

Zeng, Ting, Mengying Yang, and Yifan Shen. 2020. Fancy bitcoin and conventional financial assets: Measuring market integration based on connectedness networks. Economic Modelling 90: 209-20. [CrossRef] 